\title{
Minireview
}

\section{Stem cells, quiescence and rectal carcinoma: an unexplored relationship and potential therapeutic target}

\author{
S Buczacki', RJ Davies² and DJ Winton*,I \\ 'Cancer Research UK, Cambridge Research Institute, Li Ka Shing Centre, Robinson Way, Cambridge CB2ORE, UK; ${ }^{2}$ Cambridge Colorectal Unit, \\ Addenbrooke's Hospital, Cambridge University Hospitals NHS Foundation Trust, Cambridge CB20QQ, UK
}

\begin{abstract}
Stem cells are responsible for maintaining differentiated cell numbers during normal physiology and at times of tissue stress. They have the unique capabilities of proliferation, self-renewal, clonogenicity and multi-potentiality. It is a widely held belief that stem-like cells, known as cancer stem cells (CSCs), maintain tumours. The majority of currently identified intestinal stem cell populations appear to be rapidly cycling. However, quiescent stem cell populations have been suggested to exist in both normal intestinal crypts and tumours. Quiescent CSCs may have particular significance in the modern management of colorectal cancer making their identification and characterisation a priority. In this review, we discuss the current evidence surrounding the identification and microenvironmental control of stem cell populations in intestinal crypts and tumours as well as exploring the evidence supporting the existence of a quiescent stem and CSC population in the gut and other tissues.
\end{abstract}

British Journal of Cancer (20II) 105, 1253-1259. doi:10.1038/bjc.2011.362 www.bjcancer.com

Published online 20 September 2011

(C) 20II Cancer Research UK

Keywords: quiescence; stem cell; cancer stem cell; intestine; colorectal cancer

Over the past few decades, there have been significant advances in treatment and outcome for patients with epithelial cancers as well as our understanding of the tumour-initiating populations that drive their growth. It is now widely accepted that tumour maintenance is a function of a subset of stem-like or cancer stem cells (CSCs). Cancerous cells have various strategies to evade toxicity from chemotherapy and radiotherapy, one of which is the homeostatic phenomenon of cellular quiescence. The relative contribution of quiescent and continuously dividing stem cell populations in maintaining both normal intestinal tissue and malignant colorectal tumours remains far from clear. Both populations appear to coexist in intestine. Research from other organ systems indicates that they may have separate but cooperating functions in homeostasis and at times of injury, suggesting that the dependency on quiescence $v s$ rapid cycling stem populations may vary with biological and clinical contexts. In this regard, we highlight patients with rectal adenocarcinoma. Neoadjuvant chemoradiotherapy has led to apparent pathological complete response (pCR) in some cases but a proportion of these relapse. Here, we discuss the possible features that rectal CSC populations may adopt to result in this pattern of clinical outcome.

\section{THE CSC HYPOTHESIS}

All renewing tissues require stem cells to repopulate the differentiated cell pool that is lost as a result of physiological cell turnover. It has been shown that in tumours, there exist CSCs that drive tumour growth and that possess similar characteristics of

*Correspondence: Dr DJ Winton; E-mail: doug.winton@cancer.org.uk Received 13 June 2011; revised 15 August 2011; accepted 18 August $20 \mathrm{I}$; published online 20 September 20I I proliferation, self-renewal, clonogenicity and multi-potentiality as do stem cells in normal organs. The CSC hypothesis originates from work on haematological malignancies in the first half of the 20th century that showed only a small proportion of cells from a tumour were capable of initiating further tumour growth (Furth, 1937). It was not until 1997 that Bonnet and Dick (1997) demonstrated in acute myeloid leukaemia that this phenomenon was due to CSCs rather than stochasticity in tumour cell fate. Similar observations have subsequently been shown in a variety of solid organ tumours (Al-Hajj et al, 2003; Hermann et al, 2007; O'Brien et al, 2007), demonstrating that only a discrete subpopulation of cells have tumour-initiating capacity. It still remains unclear if these are transformed 'normal' stem cells that have undergone malignant change and yet retain their 'stem'-like characteristics or, alternatively, if they are differentiated malignant cells that have re-acquired stem-like characteristics (Chaffer et al, 2011). These two possibilities are not mutually exclusive, and in which tumours or specific circumstances either occur is not certain. It is important to note that the CSC hypothesis does not necessarily suggest that the stem cell is the cell of origin of the tumour although this may be the case in the intestine (Barker et al, 2009).

While stem cells in normal tissue are generally regarded as being rare, significant debate surrounds the prevalence of CSCs in malignancies. Much of the uncertainty surrounding this issue is a consequence of the assays widely used to assess tumourigenicity. These involve transplanting a limited number of presumed CSCs into an immunocompromised mouse and then ascertaining whether a tumour can be recreated from this subset of cells. Such assays have been criticised as the ability of the donor cells to survive and grow may be significantly compromised. For example, it has been shown using cells from human melanomas that simply changing the type of immunocompromised mouse from a 
NOD/SCID (non-obese diabetic/severe combined immunodeficient) to a NSG (NOD/SCID $\gamma$ ) mouse raises the frequency of tumour-initiating cells from 1 in a million to 1 in 4 (Quintana et al, 2008). The varying estimates of CSC prevalence could also be explained by tumour clonality and/or differentiation status; Yeung et al (2010) recently showed using a colony forming assay and colorectal (CRC) cancer cell lines that colony forming efficiency and morphology was not simply related to CSC marker presence but also to the individual cell line and therefore tumour of origin. They demonstrated that well-differentiated cell lines produced more differentiated colonies than more aggressive, undifferentiated cell lines. The conclusion being that the tumours from which the cell lines were derived may have had widely differing CSC populations: making up almost the entirety of the tumour in the latter and being a relatively small population in more differentiated lines. This interpretation is consistent with a non-differentiating CSC clonal population becoming dominant in poorly differentiated tumours.

The identification of CSCs has been dominated by the use of cell surface markers to isolate tumour cell sub-populations and subsequently assessing their tumour-initiating capacity. Interestingly, many putative CSC markers not only appear to mark CSCs from disparate tissues but also appear to overlap significantly with normal stem cell markers (Table 1). CD24, for example, has been shown to not only mark stem cells in the normal intestine (Gracz et al, 2010; von Furstenberg et al, 2011) and lung (McQualter et al, 2010) but also marks CSC populations in the colon (Vermeulen et al, 2008; Choi et al, 2009), ovary (Gao et al, 2010) and pancreas (Yao et al, 2010). Although these findings suggest overlapping regulatory functions, the picture is likely far more complex. For example, CD24 marks normal mammary stem cells (Shackleton et al, 2006) but in combination with other cell surface markers,
CD24-negative breast cancer cells are those with greatest tumourinitiating potential (Honeth et al, 2008). Further, although these cell surface markers can successfully isolate stem cell populations, the protein function may not be directly related to stem cell function.

CSCs are of clinical significance as it has been shown that they are more resistant to both chemotherapy and radiotherapy than other malignant cells (Elrick et al, 2005; Vlashi et al, 2009). This may be a biological feature retained from normal tissue stem cells that natively possess various strategies to evade chemotherapy including cellular quiescence and the expression of proteins to eliminate drugs from the cytoplasm such as $\mathrm{ABC}$ transporters (Zhou et al, 2001) and MDR proteins (Terskikh et al, 2001). Indeed, this phenomenon of drug transport has been used by some groups to isolate stem cells based on the efflux of the Hoechst DNA binding dye. If CSCs are capable of evading adjuvant treatment then disease recurrence is likely where even a few tumourinitiating cells remain after therapy (Figure 1). Identifying, characterising and developing novel targeting strategies against CSCs should not only increase the efficacy of adjuvant therapies but also enable the identification of patients at risk of disease recurrence through poor response to treatment.

\section{STEM AND CSC QUIESCENCE}

While not being essential for stem cell function, it has been suggested that quiescence is a characteristic possessed by stem cells in many mammalian tissues (Cotsarelis et al, 1990; Jensen and Watt, 2006). This may be an evolutionary selected behaviour because continuous and rapid cycling is ultimately detrimental to

Table I Stem and cancer stem cell marker overlap in the major epithelia

\begin{tabular}{|c|c|c|c|c|}
\hline Marker & Stem cell marker & Species & Cancer stem cell marker & Species \\
\hline CD24 & $\begin{array}{l}\text { Intestine (von Furstenberg et al, 20 I I) } \\
\text { Breast (Shackleton et al, 2006) } \\
\text { Lung (McQualter et al, 20 I0) } \\
\text { Neuronal (Pruszak et al, 2009) } \\
\text { Pancreas (Wang et al, 2005) }\end{array}$ & $\begin{array}{l}\text { Mus } \\
\text { Mus } \\
\text { Mus } \\
\text { Homo } \\
\text { Mus }\end{array}$ & $\begin{array}{l}\text { Intestine (Vermeulen et al, 2008) } \\
\text { Ovary (Gao et al, 20।0) } \\
\text { Pancreas (Yao et al, 20l0) }\end{array}$ & $\begin{array}{l}\text { Homo } \\
\text { Homo } \\
\text { Homo }\end{array}$ \\
\hline CD44 & $\begin{array}{l}\text { Intestine (Hou et al, 2010) } \\
\text { Prostate (Liu et al, 1997) }\end{array}$ & $\begin{array}{l}\text { Homo } \\
\text { Homo }\end{array}$ & $\begin{array}{l}\text { Intestine (Dalerba et al, 2007) } \\
\text { Breast (Al-Hajj et al, 2003) } \\
\text { Pancreas (Yao et al, 20 I0) } \\
\text { Prostate (Patrawala et al, 2006) } \\
\text { Liver (Zhu et al, 20I0) }\end{array}$ & $\begin{array}{l}\text { Homo } \\
\text { Homo } \\
\text { Homo } \\
\text { Homo } \\
\text { Homo }\end{array}$ \\
\hline CDI33 & $\begin{array}{l}\text { Intestine (Snippert et al, 2009) } \\
\text { Prostate (Richardson et al, 2004) }\end{array}$ & $\begin{array}{l}\text { Mus } \\
\text { Homo }\end{array}$ & $\begin{array}{l}\text { Intestine (O'Brien et al, 2007; Ricci-Vitiani et al, 2007) } \\
\text { Breast (Wright et al, 2008) } \\
\text { Prostate (Collins et al, 2005) } \\
\text { Ovary (Ferrandina et al, 2009) } \\
\text { Brain (Singh et al, 2004) } \\
\text { Liver (Zhu et al, 20l0) }\end{array}$ & $\begin{array}{l}\text { Homo } \\
\text { Mus } \\
\text { Homo } \\
\text { Homo } \\
\text { Homo } \\
\text { Homo }\end{array}$ \\
\hline CDI66 & Intestine (Levin et al, 2010) & $\begin{array}{l}\text { Homo } \\
\text { Mus }\end{array}$ & $\begin{array}{l}\text { Intestine (Dalerba et al, 2007) } \\
\text { Prostate (Rajasekhar et al, 20l I) }\end{array}$ & $\begin{array}{l}\text { Homo } \\
\text { Homo }\end{array}$ \\
\hline Lgr5 & $\begin{array}{l}\text { Intestine (Barker et al, 2007) } \\
\text { Skin (Jaks et al, 2008) }\end{array}$ & $\begin{array}{l}\text { Mus } \\
\text { Mus }\end{array}$ & Intestine (Barker et al, 2009) & Mus \\
\hline Olfm4 & Intestine (van der Flier et al, 2009) & Homo & Intestine (van der Flier et al, 2009) & Mus \\
\hline Aldh I & $\begin{array}{l}\text { Intestine (Huang et al, 2009) } \\
\text { Breast (Ginestier et al, 2007) }\end{array}$ & $\begin{array}{l}\text { Homo } \\
\text { Homo }\end{array}$ & $\begin{array}{l}\text { Intestine (Huang et al, 2009) } \\
\text { Breast (Ginestier et al, 2007) } \\
\text { Ovary (Kryczek et al, 20। I) } \\
\text { Lung (Liang and Shi, 20 I I) }\end{array}$ & $\begin{array}{l}\text { Homo } \\
\text { Homo } \\
\text { Homo } \\
\text { Homo }\end{array}$ \\
\hline Integrins & $\begin{array}{l}\text { Intestine (Fujimoto et al, 2002) } \\
\text { Breast (Shackleton et al, 2006) } \\
\text { Neuronal (Pruszak et al, 2009) }\end{array}$ & $\begin{array}{l}\text { Homo } \\
\text { Mus } \\
\text { Homo }\end{array}$ & $\begin{array}{l}\text { Breast (Vassilopoulos et al, 2008) } \\
\text { Prostate (Collins et al, 2005) }\end{array}$ & $\begin{array}{l}\text { Mus } \\
\text { Homo }\end{array}$ \\
\hline Bmil & $\begin{array}{l}\text { Intestine (Sangiorgi and Capecchi, 2008) } \\
\text { Neuronal (Molofsky et al, 2003) } \\
\text { Prostate (Lukacs et al, 20 I0) }\end{array}$ & $\begin{array}{l}\text { Mus } \\
\text { Mus } \\
\text { Mus }\end{array}$ & $\begin{array}{l}\text { Brain (Bruggeman et al, 2007) } \\
\text { Liver (Chiba et al, 2008) }\end{array}$ & $\begin{array}{l}\text { Mus } \\
\text { Homo }\end{array}$ \\
\hline Musashil & Intestine (Potten et al, 2003) & Mus & & \\
\hline
\end{tabular}


the stem cell population as with each sequential round of cell division there increasingly exists the probability of acquiring a cumulative burden of DNA mutations. Alternatively, it has also been suggested that quiescent stem cells exist as a conditional reservoir that only become active after periods of injury where there is loss of the rapidly cycling stem cell population ( $\mathrm{Li}$ and Clevers, 2010).

Quiescent CSCs have been isolated from melanoma (Roesch et al, 2010), ovarian (Gao et al, 2010), breast (Pece et al, 2010) and pancreatic tumours (Dembinski and Krauss, 2009). Many of these studies have utilised the phenomenon of 'label retention' in either human cell lines or mouse models to isolate putative quiescent CSCs (Figure 2). Label retaining studies involve marking all cells with a reporter protein or nucleotide analogues at a single point in time. As cells subsequently divide or die over the following days and weeks, the label is lost. Cells that are quiescent and therefore have not divided retain the label and can then be isolated for further assay. The few appropriate studies performed to date have confirmed that not only can single label retaining cells initiate tumours but they may also represent a more invasive and aggressive cell type (Mani et al, 2008; Pece et al, 2010).

Conventional chemotherapy and radiotherapy, such as is used in the treatment of rectal cancer, targets cells that are rapidly dividing. Therefore, quiescence offers CSCs a further option for evading killing. In vitro work in the haematopoietic system has confirmed that quiescent stem cells are less likely to be killed by cytotoxics (Cheng et al, 2000). There is a long standing observation of faster cell cycle times in the crypts of the distal large intestine/ rectum compared with the transverse and ascending colon, presumably to some extent as a result of increased toxic and mechanical stresses (Sunter et al, 1979). How this impacts on the balance of quiescent and cycling stem cells is unclear but it may paradoxically generate a requirement for a higher number of quiescent stem cells. Similarly it is possible that rectal cancers may also harbour higher numbers of quiescent CSCs than other intestinal tumours.
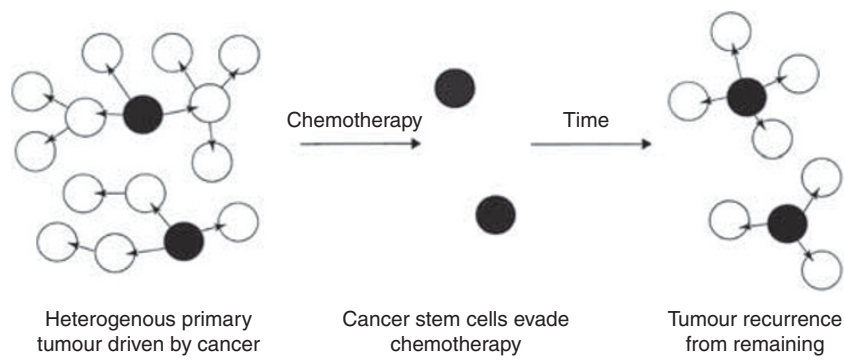

tumour driven by cancer stem cells
Cancer stem cells evade chemotherapy

\section{COLORECTAL STEM AND CSCS}

The intestine like other organs require stem cells in order to maintain adequate numbers and proportions of differentiated cells in the normal physiological state. In the small intestine, colon and rectum, these stem cells have been shown to reside in the bottom of the crypts of Lieberkûhn and are capable of driving the production of all the differentiated cell lineages of the intestine (Barker et al, 2007). These stem cells are not common; assuming a murine crypt population of around 250 cells, stem cells appear to comprise only $5 \%$ of this total population (Schepers et al, 2011). Various markers have been used to identify intestinal stem cells based in the main on the utilisation of mouse models; these include CD133 (Snippert et al, 2009; Zhu et al, 2009), CD44 (Hou et al, 2010), CD24 (Gracz et al, 2010), Bmil (Sangiorgi and Capecchi, 2008) and Lgr5 (Barker et al, 2007) (Table 2; Figure 3). Many of these identified markers have overlapping expression patterns and are often implicated in various aspects of the canonical Wnt signalling pathway, which is strongly associated with both normal intestinal stem cell function and colorectal carcinogenesis ( $\mathrm{He}$ et al, 2004; Reya and Clevers, 2005; Barker et al, 2009; Garcia et al, 2009). Several of these markers, however, have problems with specificity and while overlaying stem cell populations they also mark other non-stem cells. CD24 exemplifies this issue; while having been shown to be a bona fide stem cell marker in one marker of Paneth cells (Sato et al, 2011; von Furstenberg et al, 2011). Careful appraisal of these papers shows that CD24 has variable expression levels; while CD24 ${ }^{\mathrm{Low} / \mathrm{Mid}}$ marks the intestinal stem cell compartment, CD24 ${ }^{\text {High }}$ marks Paneth and enteroendocrine cells. Of all the markers described to date, Lgr5 has been shown to unequivocally and specifically mark the intestinal stem cell compartment as demonstrated through in vitro culture and in vivo lineage tracing studies (Barker et al, 2007).

Many normal intestinal stem cell markers also mark CSCs. Lgr5-positive cells have been shown to be representative of the cell of origin of intestinal tumourigenesis and have tumour-initiating potential (Barker et al, 2009). The degree of expression of this protein appears to relate to disease recurrence after treatment with curative intent in CRC (Merlos-Suarez et al, 2011). CD133 marks a group of cells that have tumour-initiating capacity at a greater level than CD133-negative cells (O'Brien et al, 2007). Furthermore, CD133 and CD24 expression have also been shown to relate to the degree of differentiation and invasiveness of CRC (Choi et al, 2009). However, the picture has become complicated by a study showing that loss rather than gain of membranous expression of the CSC markers CD44, CD166 and EPCAM is associated with CRC tumour progression (Lugli et al, 2010). As it has not yet been demonstrated that any one, or combination of CSC markers is capable of capturing the CSC sub-population throughout the development of a tumour, it remains possible that sub-populations may be missed.

Within the normal intestinal tract, quiescent cells have been shown to exist based on label retaining experiments. Label report, an apparently conflicting account also shows that CD24 is a

Figure I The CSC hypothesis and disease recurrence. CSCS are responsible for driving tumour growth. If CSCs rather than other malignant cells evade chemotherapy, then they can be responsible for re-establishing the tumour, clinically presenting as local recurrence or metastatic disease.

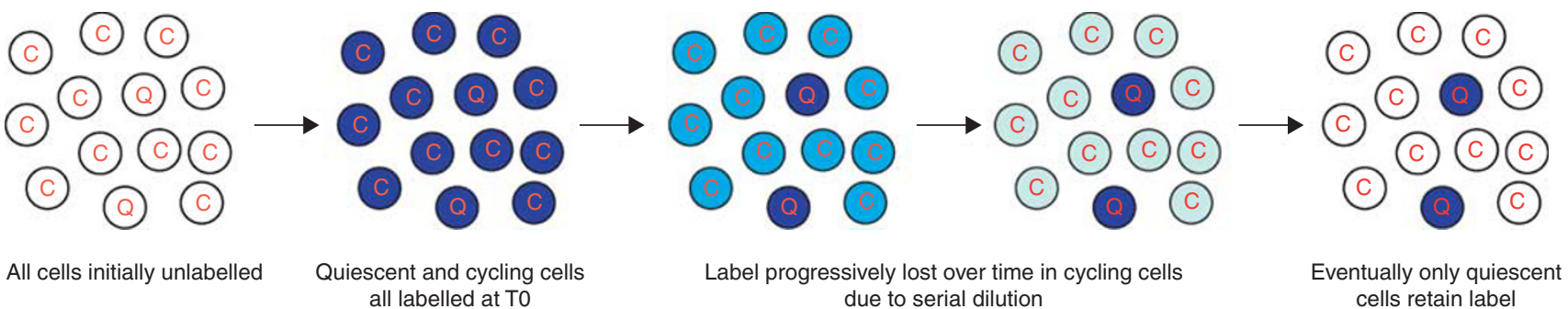

Figure 2 Label retaining cell studies. $C=$ cycling cell; $Q=$ quiescent cell. All cells are labelled with a nucleotide analogue or fluorescent reporter protein at TO. Cells that are cycling will subsequently divide thus diluting out the label. Quiescent cells retain the label enabling their isolation from the main population via FACS (fluorescence-activated cell sorting) or identification microscopically in tissue sections. 
Table 2 Intestinal stem and cancer stem cell markers

\begin{tabular}{|c|c|c|c|c|}
\hline Marker & Type of crypt cell marked & Proof of stemness ${ }^{a}$ & $\begin{array}{l}\text { Proof of cancer } \\
\text { stemness }\end{array}$ & $\begin{array}{l}\text { Number of cells required } \\
\text { for tumour growth }\end{array}$ \\
\hline CD24 & All lower crypt cells & Organoid growth & $\begin{array}{l}\text { Megacolonies } \\
\text { Xenotransplant }\end{array}$ & N/A \\
\hline CD44 & Lower crypt cells except Paneth cells & Expression profile & $\begin{array}{l}\text { Megacolonies } \\
\text { Xenotransplant }\end{array}$ & $200-500^{c}$ \\
\hline CDI33 & All lower crypt cells & In vivo lineage tracing & Xenotransplant & $3000^{c}, 262^{d}$ \\
\hline CDI66 & Intercalated crypt base cells and Paneth cells & $\begin{array}{l}\text { Expression profile } \\
\text { Immunofluorescence } \\
\text { FACS }\end{array}$ & Xenotransplant & $1000-4000^{c}$ \\
\hline Lgr5 & Intercalated crypt base cells & In vivo lineage tracing & Targeted Apc deletion & N/A \\
\hline Olfm4 & Intercalated crypt base cells & In situ hybridisation & In situ hybridisation & N/A \\
\hline Aldh | & Isolated crypt base cells & Immunofluorescence & Xenotransplant & $25^{e}$ \\
\hline Integrins & All lower I/3 crypt cells ( $\beta$ | integrin) & Colony forming assay & N/A & N/A \\
\hline Bmil & +4 Single supra-Paneth cell & In vivo lineage tracing & N/A & N/A \\
\hline Musashil & Intercalated crypt base and supra-Paneth cells & Immunohistochemistry & N/A & N/A \\
\hline
\end{tabular}

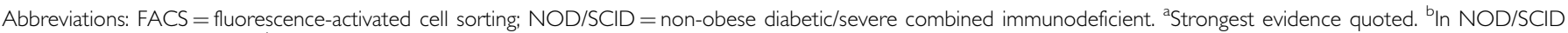
mice. 'Dalerba et al (2007). 'O'Brien et al (2007). " Huang et al (2009).

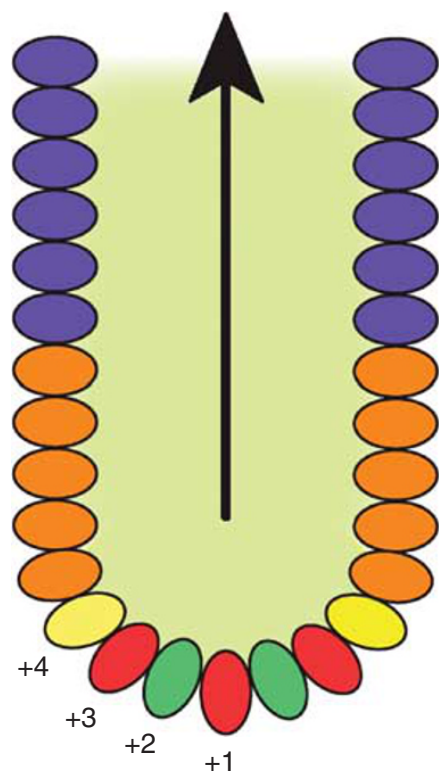

Figure 3 Functional arrangement of cells within small intestinal crypts. Crypts are glandular monolayer epithelial invaginations in the intestinal wall from which differentiated cells arise. In the small intestine, immunological terminally differentiated Paneth cells (red) reside in the crypt base. Interspersed between the Paneth cells are found intercalated crypt base cells (green), which are marked by Lgr5 and have been shown to be homeostatic stem cells. Above the Paneth and stem cell zone, in the +4 position, is found the location where the majority of label retaining cells (yellow) reside. Above this is known as the transit amplifying zone (brown) through which cells migrate and terminally differentiate on their way to the upper crypt (blue) and eventually the villus.

retention, however, only identifies quiescence per se and does not prove 'stemness'. Lgr5-positive cells are rapidly cycling and have been shown using a variety of approaches to have a cell cycle time approximating to around $24 \mathrm{~h}$ (Escobar et al, 2011; Schepers et al, 2011). Also, by analysis of clonal population dynamics, it has been shown that in the physiological situation, there can exist only one equipotent but potentially heterogeneous stem cell population (Lopez-Garcia et al, 2010). These data suggest that the whole intestinal stem compartment in normal physiology is rapidly cycling but they do not address the possibility of plasticity during times of injury, that is, a cell acquiring stem-like characteristics. A quiescent 'reserve' cell with label retaining features may represent the quiescent stem cell. Various markers including Bmil (Sangiorgi and Capecchi, 2008), Wip1 (Demidov et al, 2007), pPTEN (He et al, 2004), DCAMKL-1 (May et al, 2009) and more recently mTert (mouse telomerase reverse transcriptase) (Montgomery et al, 2011) have been shown to overlay the position where label retaining cells are most commonly found known as the supraPaneth cell position +4 (the cell position from the crypt base). Debate, however, surrounds whether indeed these are truly a separate and quiescent stem cell population or an overlapping population with rapidly cycling Lgr5 stem cells. These putative quiescent cells have in some cases been shown to be capable of clonogenic expansion in vivo (Sangiorgi and Capecchi, 2008). In the case of mTert cells, intriguingly this clonogenicity increases after radiation induced epithelial insult. mTert as well as being a marker, may have a significant functional role as well. Maintenance of telomeres is essential for cells to avoid senescence after repeated rounds of division and therefore increased expression of mTert would be beneficial for stem and CSCs.

The existence of quiescent colonic and rectal CSCs remains largely unexplored not in the least due to the current lack of a definitive marker. The identification of their counterparts in the normal intestine suggests an important possible role for quiescent CSCs in CRC. For example, if Tert-positive cells are present in rectal cancers and show increased stem-like behaviour after radiotherapy, then they may provide a potential explanation for both poor response to neoadjuvant chemoradiotherapy and recurrent disease.

\section{THE ROLE OF THE NICHE IN PHYSIOLOGY, TUMOURIGENESIS AND REGULATION OF QUIESCENCE}

It is becoming increasingly evident that microenvironmental or 'niche' cues have an instrumental role in determining stem cell function and fate as well as CSC plasticity and tumour development. Recent developments using in vitro organoid culture as well as in vivo data have shown that both the mesenchyme and Paneth cells constitute the niche that provides intestinal stem cells with tightly co-ordinated signals to enable normal function involving Wnt, Notch and BMP pathways (He et al, 2004; Sato et al, 2009, 2011). Given the location of quiescent intestinal stem cells in the +4 position and in a different geographical location to that of Lgr5 + cells in the intercalated positions, they may be exposed to different signals. Indeed as well as providing instructions about 
differentiation, Wnt and BMP signalling also regulate proliferation. Modulations of these signals may have a direct effect on cell cycle times and account for the apparent quiescence seen at the +4 position. There is support for such regulation from epidermal studies, demonstrating that Wnt inhibition promotes stem cell quiescence (Nishikawa and Osawa, 2007). Given how reliant both skin and intestinal stem cells are on Wnt and BMP signalling, it is possible that markers of quiescent skin stem cell populations such as Lrig1 and the NFATs may mark quiescent counterparts in the intestine (Jensen and Watt, 2006; Horsley et al, 2008).

CSCs also require a niche. Modulation of Wnt signalling by myofibroblasts secreting hepatocyte growth factor has been shown to account for cancer cells' stemness (Vermeulen et al, 2010). It has also been proposed that inflammation and hypoxia provide microenvironmental cues to alter tumour cell behaviour (Grivennikov et al, 2009; Yeung et al, 2011). This suggests that responses to or mediated by tumours can generate novel environments that are exploited by cancer cells. Looking at wider systems it appears that these types of cues also regulate quiescence and therefore similar mechanisms may be at play in the intestine and CRC (Hermitte et al, 2006). Changes in CSC microenvironment are inevitable after neoadjuvant chemoradiotherapy in rectal cancer and could have important clinical ramifications including changing the balance between quiescent and rapidly cycling CSCs.

\section{CLINICAL IMPLICATIONS IN THE MANAGEMENT OF RECTAL CANCER}

Modern treatment of rectal cancer is multi-disciplinary involving several modalities. After histological confirmation of malignancy, subsequent treatment options are determined by radiological staging of both the primary tumour and the surrounding mesorectum, as well as an assessment for macroscopic metastatic spread. Small tumours that have no local or regional spread may proceed directly to surgical resection whereas more advanced tumours will receive either preoperative radiotherapy to reduce the risk of local recurrence or neoadjuvant chemoradiotherapy in order to downstage the primary tumour. This downstaging process is aimed at enabling complete surgical excision with a tumour-free circumferential resection margin. It is becoming increasingly apparent that a significant proportion of patients who receive neoadjuvant chemoradiotherapy have an excellent response and while most patients at present still proceed to surgical resection, in $15-27 \%$ there is often no residual tumour seen in the resected specimen; a phenomenon known as pCR (Maas et al, 2010). Whether these patients still require surgical resection of the rectum with its incumbent morbidity and mortality is currently under much debate. Several groups have looked at whether there are molecular markers or dominant signalling pathways to predict which patients will respond to neoadjuvant therapy and which will not. The Wnt and insulin signalling pathways (Spitzner et al, 2010), VEGF and EGFR levels (Toiyama et al, 2010) as well as the apoptotic index (Rodel et al, 2002) have all been implicated in responsiveness. It is likely however that the issue is far more complex than simply whether a tumour responds to neoadjuvant treatment or not. A recent pooled analysis of studies, comparing patients with pCR and those without, shows that while patients with PCR have a more favourable outcome there still exists a significant proportion of these patients who will succumb with either local recurrence or distant metastases (Maas et al, 2010). In patients with pCR, this study showed 5-year disease-free survival was $83.3 \%$ and there was a $2.8 \% 5$-year risk for local recurrence. Even where a tumour is seen to have completely responded on pathological staging, any surviving CSC population no matter how small and present either locally or in the form of circulating tumour cells could potentially cause local recurrence or distant metastasis. Given that, by definition, all of the local tumour population is eliminated by neoadjuvant treatment in situations of pCR it is likely that the tumour-initiating cell population that is responsible for disease recurrence will be a very small population when compared with the total tumour population. Existing CSC markers tend to mark significant areas of a primary tumour volume that probably represent expansion of a dominant clone (Choi et al, 2009; Snippert et al, 2009; Lugli et al, 2010). A rare population of quiescent CSCs have the prevalence and biological behaviour to account for this pattern of disease recurrence.

Aside from isolation and characterisation of quiescent CSCs, there are several areas that could form the focus for further research. First, if one could identify rectal tumours that had significant populations of chemoradiotherapy-resistant cells present before neoadjuvant therapy was given, then it might make subsequent patient selection for surgical resection simpler. While many CSC populations are inherently resistant to chemotherapy and radiotherapy the histological or imaging directed identification of a putative quiescent CSC population within rectal tumours should form one avenue for future studies.

Obviously, the development of drugs to target quiescent CSCs will be of utmost importance should they be shown to have tumourigenic capacity. As well as cell-specific targeting, drugs that modulate niche signalling may be helpful in both altering cell kinetics and rendering quiescent cells vulnerable but also in forcing quiescent CSC differentiation. However, it is not solely the development of new drugs that is going to improve survival rates. Current thinking increasingly leans towards dynamism existing within stem cell populations where the biological properties of any one stem cell can change stochastically over time. If this is representative of the situation in CSCs within rectal cancers, then it implies the importance of targeting all the differentiated cells and CSCs either rapidly cycling or quiescent in the tumour at the time of therapeutic intervention concurrently by polypharmacy. Therefore, timing of chemotherapy as well as choice of drug will be of equal importance.

Based on work to date in the intestine and other tissues, the elusive quiescent intestinal stem cell is likely to exist and its presence will have significant implications not only for intestinal stem cell biology but also for the biology and treatment of rectal cancer. As rapidly cycling intestinal stem cells become increasingly well characterised, the issues of dynamism and plasticity in stem cell compartments suggests that time and resources should also be directed towards the understanding of this lesser known but equally important intestinal stem cell population.

\section{REFERENCES}

Al-Hajj M, Wicha MS, Benito-Hernandez A, Morrison SJ, Clarke MF (2003) Prospective identification of tumorigenic breast cancer cells. Proc Nat Acad Sci USA 100: 3983-3988

Barker N, Ridgway RA, van Es JH, van de Wetering M, Begthel H, van den Born M, Danenberg E, Clarke AR, Sansom OJ, Clevers H (2009) Crypt stem cells as the cells-of-origin of intestinal cancer. Nature 457: $608-611$ 
Bruggeman SW, Hulsman D, Tanger E, Buckle T, Blom M, Zevenhoven J, van Tellingen O, van Lohuizen M (2007) Bmil controls tumor development in an Ink4a/Arf-independent manner in a mouse model for glioma. Cancer Cell 12: $328-341$

Chaffer CL, Brueckmann I, Scheel C, Kaestli AJ, Wiggins PA, Rodrigues LO, Brooks M, Reinhardt F, Su Y, Polyak K, Arendt LM, Kuperwasser C, Bierie B, Weinberg RA (2011) Normal and neoplastic nonstem cells can spontaneously convert to a stem-like state. Proc Natl Acad Sci USA 108: 7950 - 7955

Cheng T, Rodrigues N, Shen H, Yang Y, Dombkowski D, Sykes M, Scadden DT (2000) Hematopoietic stem cell quiescence maintained by p21cip1/ waf1. Science 287: $1804-1808$

Chiba T, Miyagi S, Saraya A, Aoki R, Seki A, Morita Y, Yonemitsu Y, Yokosuka O, Taniguchi H, Nakauchi H, Iwama A (2008) The polycomb gene product BMI1 contributes to the maintenance of tumor-initiating side population cells in hepatocellular carcinoma. Cancer Res 68: $7742-7749$

Choi D, Lee HW, Hur KY, Kim JJ, Park GS, Jang SH, Song YS, Jang KS, Paik SS (2009) Cancer stem cell markers CD133 and CD24 correlate with invasiveness and differentiation in colorectal adenocarcinoma. World $J$ Gastroenterol 15: 2258-2264

Collins AT, Berry PA, Hyde C, Stower MJ, Maitland NJ (2005) Prospective identification of tumorigenic prostate cancer stem cells. Cancer Res 65: $10946-10951$

Cotsarelis G, Sun TT, Lavker RM (1990) Label-retaining cells reside in the bulge area of pilosebaceous unit: implications for follicular stem cells, hair cycle, and skin carcinogenesis. Cell 61: 1329-1337

Dalerba P, Dylla SJ, Park IK, Liu R, Wang X, Cho RW, Hoey T, Gurney A, Huang EH, Simeone DM, Shelton AA, Parmiani G, Castelli C, Clarke MF (2007) Phenotypic characterization of human colorectal cancer stem cells. Proc Natl Acad Sci USA 104: 10158-10163

Dembinski JL, Krauss S (2009) Characterization and functional analysis of a slow cycling stem cell-like subpopulation in pancreas adenocarcinoma. Clin Exp Metastasis 26: 611-623

Demidov ON, Timofeev O, Lwin HN, Kek C, Appella E, Bulavin DV (2007) Wip1 phosphatase regulates p53-dependent apoptosis of stem cells and tumorigenesis in the mouse intestine. Cell Stem Cell 1: $180-190$

Elrick LJ, Jorgensen HG, Mountford JC, Holyoake TL (2005) Punish the parent not the progeny. Blood 105: $1862-1866$

Escobar M, Nicolas P, Sangar F, Laurent-Chabalier S, Clair P, Joubert D, Jay P, Legraverend C (2011) Intestinal epithelial stem cells do not protect their genome by asymmetric chromosome segregation. Nat Commun 2: 258

Ferrandina G, Martinelli E, Petrillo M, Prisco MG, Zannoni G, Sioletic S, Scambia G (2009) CD133 antigen expression in ovarian cancer. BMC Cancer 9: 221

Fujimoto K, Beauchamp RD, Whitehead RH (2002) Identification and isolation of candidate human colonic clonogenic cells based on cell surface integrin expression. Gastroenterology 123: $1941-1948$

Furth J KM (1937) The transmission of leukaemia of mice with a single cell. Am J Cancer 31: 276-282

Gao MQ, Choi YP, Kang S, Youn JH, Cho NH (2010) CD24+ cells from hierarchically organized ovarian cancer are enriched in cancer stem cells. Oncogene 29: 2672-2680

Garcia MI, Ghiani M, Lefort A, Libert F, Strollo S, Vassart G (2009) LGR5 deficiency deregulates Wnt signaling and leads to precocious Paneth cell differentiation in the fetal intestine. Dev Biol 331: 58-67

Ginestier C, Hur MH, Charafe-Jauffret E, Monville F, Dutcher J, Brown M, Jacquemier J, Viens P, Kleer CG, Liu S, Schott A, Hayes D, Birnbaum D, Wicha MS, Dontu G (2007) ALDH1 is a marker of normal and malignant human mammary stem cells and a predictor of poor clinical outcome. Cell Stem Cell 1: 555-567

Gracz AD, Ramalingam S, Magness ST (2010) Sox9 expression marks a subset of CD24-expressing small intestine epithelial stem cells that form organoids in vitro. Am J Physiol Gastrointest Liver Physiol 298: G590 - G600

Grivennikov S, Karin E, Terzic J, Mucida D, Yu GY, Vallabhapurapu S, Scheller J, Rose-John S, Cheroutre H, Eckmann L, Karin M (2009) IL-6 and Stat3 are required for survival of intestinal epithelial cells and development of colitis-associated cancer. Cancer Cell 15: 103-113

He XC, Zhang J, Tong WG, Tawfik O, Ross J, Scoville DH, Tian Q, Zeng X, He X, Wiedemann LM, Mishina Y, Li L (2004) BMP signaling inhibits intestinal stem cell self-renewal through suppression of Wnt-betacatenin signaling. Nat Genet 36: $1117-1121$
Hermann PC, Huber SL, Herrler T, Aicher A, Ellwart JW, Guba M, Bruns CJ, Heeschen C (2007) Distinct populations of cancer stem cells determine tumor growth and metastatic activity in human pancreatic cancer. Cell Stem Cell 1: 313-323

Hermitte F, Brunet de la Grange P, Belloc F, Praloran V, Ivanovic Z (2006) Very low $\mathrm{O} 2$ concentration $(0.1 \%)$ favors G0 return of dividing CD34+ cells. Stem Cells 24: $65-73$

Honeth G, Bendahl PO, Ringner M, Saal LH, Gruvberger-Saal SK, Lovgren K, Grabau D, Ferno M, Borg A, Hegardt C (2008) The CD44+/CD24phenotype is enriched in basal-like breast tumors. Breast Cancer Res 10: R53

Horsley V, Aliprantis AO, Polak L, Glimcher LH, Fuchs E (2008) NFATc1 balances quiescence and proliferation of skin stem cells. Cell 132: 299-310

Hou NY, Yang K, Chen T, Chen XZ, Zhang B, Mo XM, Hu JK (2010) CD133(+)CD44 (+) subgroups may be human small intestinal stem cells. Mol Biol Rep 38(2): $997-1004$

Huang EH, Hynes MJ, Zhang T, Ginestier C, Dontu G, Appelman H, Fields JZ, Wicha MS, Boman BM (2009) Aldehyde dehydrogenase 1 is a marker for normal and malignant human colonic stem cells (SC) and tracks SC overpopulation during colon tumorigenesis. Cancer Res 69: 3382-3389

Jaks V, Barker N, Kasper M, van Es JH, Snippert HJ, Clevers H, Toftgard R (2008) Lgr5 marks cycling, yet long-lived, hair follicle stem cells. Nat Genet 40: $1291-1299$

Jensen KB, Watt FM (2006) Single-cell expression profiling of human epidermal stem and transit-amplifying cells: Lrig1 is a regulator of stem cell quiescence. Proc Natl Acad Sci USA 103: 11958-11963

Kryczek I, Liu S, Roh M, Vatan L, Szeliga W, Wei S, Banerjee M, Mao Y, Kotarski J, Wicha MS, Liu R, Zou W (2011) Expression of aldehyde dehydrogenase and CD133 defines ovarian cancer stem cells. Int $J$ Cancer; e-pub ahead of print 8 April 2011

Levin TG, Powell AE, Davies PS, Silk AD, Dismuke AD, Anderson EC, Swain JR, Wong MH (2010) Characterization of the intestinal cancer stem cell marker, CD166/ALCAM, in the human and mouse gastrointestinal tract. Gastroenterology 139: $2072-2082$

Li L, Clevers H (2010) Coexistence of quiescent and active adult stem cells in mammals. Science 327: $542-545$

Liang D, Shi Y (2011) Aldehyde dehydrogenase-1 is a specific marker for stem cells in human lung adenocarcinoma. Med Oncol; e-pub ahead of print 12 April 2011

Liu AY, True LD, LaTray L, Nelson PS, Ellis WJ, Vessella RL, Lange PH, Hood L, van den Engh G (1997) Cell-cell interaction in prostate gene regulation and cytodifferentiation. Proc Natl Acad Sci USA 94: $10705-10710$

Lopez-Garcia C, Klein AM, Simons BD, Winton DJ (2010) Intestinal stem cell replacement follows a pattern of neutral drift. Science 330: $822-825$

Lugli A, Iezzi G, Hostettler I, Muraro MG, Mele V, Tornillo L, Carafa V, Spagnoli G, Terracciano L, Zlobec I (2010) Prognostic impact of the expression of putative cancer stem cell markers CD133, CD166, CD44s, EpCAM, and ALDH1 in colorectal cancer. Br J Cancer 103: $382-390$

Lukacs RU, Memarzadeh S, Wu H, Witte ON (2010) Bmi-1 is a crucial regulator of prostate stem cell self-renewal and malignant transformation. Cell Stem Cell 7: 682-693

Maas M, Nelemans PJ, Valentini V, Das P, Rodel C, Kuo LJ, Calvo FA, Garcia-Aguilar J, Glynne-Jones R, Haustermans K, Mohiuddin M, Pucciarelli S, Small Jr W, Suarez J, Theodoropoulos G, Biondo S, Beets-Tan RG, Beets GL (2010) Long-term outcome in patients with a pathological complete response after chemoradiation for rectal cancer: a pooled analysis of individual patient data. Lancet Oncol 11: 835-844

Mani SA, Guo W, Liao MJ, Eaton EN, Ayyanan A, Zhou AY, Brooks M, Reinhard F, Zhang CC, Shipitsin M, Campbell LL, Polyak K, Brisken C, Yang J, Weinberg RA (2008) The epithelial-mesenchymal transition generates cells with properties of stem cells. Cell 133: 704-715

May R, Sureban SM, Hoang N, Riehl TE, Lightfoot SA, Ramanujam R, Wyche JH, Anant S, Houchen CW (2009) Doublecortin and CaM kinaselike-1 and leucine-rich-repeat-containing G-protein-coupled receptor mark quiescent and cycling intestinal stem cells, respectively. Stem Cells 27: $2571-2579$

McQualter JL, Yuen K, Williams B, Bertoncello I (2010) Evidence of an epithelial stem/progenitor cell hierarchy in the adult mouse lung. Proc Natl Acad Sci USA 107: 1414-1419

Merlos-Suarez A, Barriga FM, Jung P, Iglesias M, Cespedes MV, Rossell D, Sevillano M, Hernando-Momblona X, da Silva-Diz V, Munoz P, Clevers $\mathrm{H}$, Sancho E, Mangues R, Batlle E (2011) The intestinal stem cell 
signature identifies colorectal cancer stem cells and predicts disease relapse. Cell Stem Cell 8: 511-524

Molofsky AV, Pardal R, Iwashita T, Park IK, Clarke MF, Morrison SJ (2003) Bmi-1 dependence distinguishes neural stem cell self-renewal from progenitor proliferation. Nature 425: $962-967$

Montgomery RK, Carlone DL, Richmond CA, Farilla L, Kranendonk ME, Henderson DE, Baffour-Awuah NY, Ambruzs DM, Fogli LK, Algra S, Breault DT (2011) Mouse telomerase reverse transcriptase (mTert) expression marks slowly cycling intestinal stem cells. Proc Natl Acad Sci USA 108: $179-184$

Nishikawa S, Osawa M (2007) Generating quiescent stem cells. Pigment Cell Res 20: $263-270$

O'Brien CA, Pollett A, Gallinger S, Dick JE (2007) A human colon cancer cell capable of initiating tumour growth in immunodeficient mice. Nature 445: $106-110$

Patrawala L, Calhoun T, Schneider-Broussard R, Li H, Bhatia B, Tang S, Reilly JG, Chandra D, Zhou J, Claypool K, Coghlan L, Tang DG (2006) Highly purified CD44+ prostate cancer cells from xenograft human tumors are enriched in tumorigenic and metastatic progenitor cells. Oncogene 25: 1696-1708

Pece S, Tosoni D, Confalonieri S, Mazzarol G, Vecchi M, Ronzoni S, Bernard L, Viale G, Pelicci PG, Di Fiore PP (2010) Biological and molecular heterogeneity of breast cancers correlates with their cancer stem cell content. Cell 140: $62-73$

Potten CS, Booth C, Tudor GL, Booth D, Brady G, Hurley P, Ashton G, Clarke R, Sakakibara S, Okano H (2003) Identification of a putative intestinal stem cell and early lineage marker; musashi-1. Differentiation 71: $28-41$

Pruszak J, Ludwig W, Blak A, Alavian K, Isacson O (2009) CD15, CD24, and CD29 define a surface biomarker code for neural lineage differentiation of stem cells. Stem Cells 27: 2928-2940

Quintana E, Shackleton M, Sabel MS, Fullen DR, Johnson TM, Morrison SJ (2008) Efficient tumour formation by single human melanoma cells. Nature 456: 593-598

Rajasekhar VK, Studer L, Gerald W, Socci ND, Scher HI (2011) Tumourinitiating stem-like cells in human prostate cancer exhibit increased NFkappaB signalling. Nat Commun 2: 162

Reya T, Clevers H (2005) Wnt signalling in stem cells and cancer. Nature 434: $843-850$

Ricci-Vitiani L, Lombardi DG, Pilozzi E, Biffoni M, Todaro M, Peschle C, De Maria R (2007) Identification and expansion of human colon-cancerinitiating cells. Nature 445: 111-115

Richardson GD, Robson CN, Lang SH, Neal DE, Maitland NJ, Collins AT (2004) CD133, a novel marker for human prostatic epithelial stem cells. $J$ Cell Sci 117: 3539-3545

Rodel C, Grabenbauer GG, Papadopoulos T, Bigalke M, Gunther K, Schick C, Peters A, Sauer R, Rodel F (2002) Apoptosis as a cellular predictor for histopathologic response to neoadjuvant radiochemotherapy in patients with rectal cancer. Int J Radiat Oncol Biol Phys 52: 294-303

Roesch A, Fukunaga-Kalabis M, Schmidt EC, Zabierowski SE, Brafford PA, Vultur A, Basu D, Gimotty P, Vogt T, Herlyn M (2010) A temporarily distinct subpopulation of slow-cycling melanoma cells is required for continuous tumor growth. Cell 141: 583-594

Sangiorgi E, Capecchi MR (2008) Bmil is expressed in vivo in intestinal stem cells. Nat Genet 40: 915-920

Sato T, van Es JH, Snippert HJ, Stange DE, Vries RG, van den Born M, Barker N, Shroyer NF, van de Wetering M, Clevers H (2011) Paneth cells constitute the niche for Lgr5 stem cells in intestinal crypts. Nature 469(7330): 415-418

Sato T, Vries RG, Snippert HJ, van de Wetering M, Barker N, Stange DE, van Es JH, Abo A, Kujala P, Peters PJ, Clevers H (2009) Single Lgr5 stem cells build crypt-villus structures in vitro without a mesenchymal niche. Nature 459: $262-265$

Schepers AG, Vries R, van den Born M, van de Wetering M, Clevers H (2011) Lgr5 intestinal stem cells have high telomerase activity and randomly segregate their chromosomes. EMBO J 30: 1104-1109

Shackleton M, Vaillant F, Simpson KJ, Stingl J, Smyth GK, Asselin-Labat $\mathrm{ML}, \mathrm{Wu}$ L, Lindeman GJ, Visvader JE (2006) Generation of a functional mammary gland from a single stem cell. Nature 439: 84-88

Singh SK, Hawkins C, Clarke ID, Squire JA, Bayani J, Hide T, Henkelman RM, Cusimano MD, Dirks PB (2004) Identification of human brain tumour initiating cells. Nature 432: 396-401
Snippert $\mathrm{HJ}$, van Es $\mathrm{JH}$, van den Born $\mathrm{M}$, Begthel $\mathrm{H}$, Stange $\mathrm{DE}$, Barker N, Clevers H (2009) Prominin-1/CD133 marks stem cells and early progenitors in mouse small intestine. Gastroenterology 136: 2187-2194. e1

Spitzner M, Emons G, Kramer F, Gaedcke J, Rave-Frank M, Scharf JG, Burfeind P, Becker H, Beissbarth T, Ghadimi BM, Ried T, Grade M (2010) A gene expression signature for chemoradiosensitivity of colorectal cancer cells. Int J Radiat Oncol Biol Phys 78: 1184-1192

Sunter JP, Appleton DR, De Rodriguez MS, Wright NA, Watson AJ (1979) A comparison of cell proliferation at different sites within the large bowel of the mouse. J Anat 129: 833-842

Terskikh AV, Easterday MC, Li L, Hood L, Kornblum HI, Geschwind DH, Weissman IL (2001) From hematopoiesis to neuropoiesis: evidence of overlapping genetic programs. Proc Natl Acad Sci USA 98: 7934-7939

Toiyama Y, Inoue Y, Saigusa S, Okugawa Y, Yokoe T, Tanaka K, Miki C, Kusunoki M (2010) Gene expression profiles of epidermal growth factor receptor, vascular endothelial growth factor and hypoxia-inducible factor-1 with special reference to local responsiveness to neoadjuvant chemoradiotherapy and disease recurrence after rectal cancer surgery. Clin Oncol (R Coll Radiol) 22: 272-280

van der Flier LG, Haegebarth A, Stange DE, van de Wetering $M$, Clevers H (2009) OLFM4 is a robust marker for stem cells in human intestine and marks a subset of colorectal cancer cells. Gastroenterology 137: $15-17$

Vassilopoulos A, Wang RH, Petrovas C, Ambrozak D, Koup R, Deng CX (2008) Identification and characterization of cancer initiating cells from BRCA1 related mammary tumors using markers for normal mammary stem cells. Int J Biol Sci 4: 133-142

Vermeulen L, De Sousa EMF, van der Heijden M, Cameron K, de Jong JH, Borovski T, Tuynman JB, Todaro M, Merz C, Rodermond H, Sprick MR, Kemper K, Richel DJ, Stassi G, Medema JP (2010) Wnt activity defines colon cancer stem cells and is regulated by the microenvironment. Nat Cell Biol 12: $468-476$

Vermeulen L, Todaro M, de Sousa Mello F, Sprick MR, Kemper K, Perez Alea M, Richel DJ, Stassi G, Medema JP (2008) Single-cell cloning of colon cancer stem cells reveals a multi-lineage differentiation capacity. Proc Natl Acad Sci USA 105: 13427 - 13432

Vlashi E, McBride WH, Pajonk F (2009) Radiation responses of cancer stem cells. J Cell Biochem 108: 339-342

von Furstenberg RJ, Gulati AS, Baxi A, Doherty JM, Stappenbeck TS, Gracz AD, Magness ST, Henning SJ (2011) Sorting mouse jejunal epithelial cells with CD24 yields a population with characteristics of intestinal stem cells. Am J Physiol Gastrointest Liver Physiol 300: G409-G417

Wang X, Hu J, Zhao D, Wang G, Tan L, Du L, Yang J, Hou L, Zhang H, Yu Y, Deng H, Ding M (2005) NestinnegCD24low/- population from fetal Nestin-EGFP transgenic mice enriches the pancreatic endocrine progenitor cells. Pancreas 31: 385-391

Wright MH, Calcagno AM, Salcido CD, Carlson MD, Ambudkar SV, Varticovski L (2008) Brcal breast tumors contain distinct CD44+/CD24and CD133+ cells with cancer stem cell characteristics. Breast Cancer Res 10: R10

Yao J, Cai HH, Wei JS, An Y, Ji ZL, Lu ZP, Wu JL, Chen P, Jiang KR, Dai CC, Qian ZY, Xu ZK, Miao Y (2010) Side population in the pancreatic cancer cell lines SW1990 and CFPAC-1 is enriched with cancer stem-like cells. Oncol Rep 23: 1375 - 1382

Yeung TM, Gandhi SC, Bodmer WF (2011) Hypoxia and lineage specification of cell line-derived colorectal cancer stem cells. Proc Natl Acad Sci USA 108: $4382-4387$

Yeung TM, Gandhi SC, Wilding JL, Muschel R, Bodmer WF (2010) Cancer stem cells from colorectal cancer-derived cell lines. Proc Natl Acad Sci USA 107: $3722-3727$

Zhou S, Schuetz JD, Bunting KD, Colapietro AM, Sampath J, Morris JJ, Lagutina I, Grosveld GC, Osawa M, Nakauchi H, Sorrentino BP (2001) The $\mathrm{ABC}$ transporter Bcrp1/ABCG2 is expressed in a wide variety of stem cells and is a molecular determinant of the side-population phenotype. Nat Med 7: $1028-1034$

Zhu L, Gibson P, Currle DS, Tong Y, Richardson RJ, Bayazitov IT, Poppleton H, Zakharenko S, Ellison DW, Gilbertson RJ (2009) Prominin 1 marks intestinal stem cells that are susceptible to neoplastic transformation. Nature 457: 603-607

Zhu Z, Hao X, Yan M, Yao M, Ge C, Gu J, Li J (2010) Cancer stem/ progenitor cells are highly enriched in CD133+CD44+ population in hepatocellular carcinoma. Int J Cancer 126: 2067-2078 